\title{
METODE SOSIALISASI PRODUK PADA RUMAH ZAKAT CABANG MAKASSAR
}

\author{
Samsul, Fadli L. Laonso \\ Dosen Program Studi Ekonomi Syari'ah \\ STAI Al-Azhar Gowa
}

\begin{abstract}
Abstrak: Penelitian ini dilakukan bertujuan untuk mengetahui implementasi sosialisasi produk (program) pada RZ Cabang Makassar serta bagaimana penerapannya pada masyarakat Kota Makassar dan kendala-kendala yang dihadapinya. Metode yang digunakan dalam penelitian ini adalah metode kualitatif deskriptif. Hasil penelitian ini, ditemukan bahwa Lembaga Amil Zakat Nasional (LAZNAS) RZ Cabang Makassar dalam melakukan sosialisasi produk/program pada masyarakat, menggunakan metode-metode adaptasi (face to face) langsung dengan masyarakat. Adapun kendala-kendala yang dihadapi dalam implementasi sosialisasi produk (program) adalah sering terlambatnya dana zakat yang terkumpul dari muzakki dan masalah SDM Relawan sebagai pionir kreativitas RZ Cabang Makassar.
\end{abstract}

Kata Kunci: Metode, Sosialisasi, Produk, dan Rumah Zakat.

\section{PENDAHULUAN}

akat merupakan rukun Islam ketiga yang menjadi faktor penting dalam mengatasi permasalahan ekonomi umat. Selain itu, zakat adalah ibadah maaliyah ijtima'iyyah yang memiliki peran strategis dan menentukan
kesejahteraan umat ${ }^{1}$ serta mempengaruhi aktivitas ekonomi secara
nasional. Zakat merupakan salah satu ibadah pokok kepada Allah swt.
sehingga keberadaannya dianggap sebagai Ma'lum min ad-Dien bi Adh-
Dharurah atau diketahui secara otomatis keberadaannya dan merupakan bagian mutlak dari keislaman seseorang.

Munculnya Undang-Undang RI No. 23 Tahun 2011 secara khusus telah mengukuhkan urgensi lembaga pengelolah zakat di Indonesia atau lebih dikenal dengan Lembaga Amil Zakat Nasional (LAZNAS) yang sebelumnya pemerintah telah menerbitkan Undang-undang RI No. 38 Tahun 1999 pada Bab III pasal 6 dan 7 tentang pengelolaan zakat menyatakan bahwa lembaga zakat di Indonesia terdiri dari Badan Amil Zakat (BAZ) dan Lembaga Amil Zakat (LAZ). Badan Amil Zakat dibentuk oleh pemerintah serta Lembaga Amil Zakat didirikan oleh masyarakat. ${ }^{2}$ Dan salah satu Lembaga Amil Zakat Nasional (LAZNAS) yang didirikan oleh masyarakat adalah Rumah Zakat.

\footnotetext{
${ }^{1}$ Yusuf al-Qardhawi, Al-Ibadah fil-Islam ( Beirut: Muassasah Risalah, 1993 ), h. 235.

${ }^{2}$ Undang-Undang Republik Indonesia No. 38 Tahun 1999 Tentang Pengelolaan Zakat.
} 
Pada tahun 2015, Rumah Zakat Cabang Makassar sebagai salah satu lembaga yang fokus untuk mengumpulkan, mengelola dan menyalurkan dana ZIS kepada masyarakat, hanya berhasil mengumpulkan dana zakat sebesar Rp. 1,21 Milyar serta sebelumnya ditahun 2014 dana zakat yang terkumpul sebesar Rp. 1,25 Milyar. $^{3}$ Hal ini mengindikasikan Rumah Zakat Cabang Makassar mengalami penurunan donasi sekitar $0,04 \%$.

Setiap usaha baik yang bergerak di bidang profit maupun non profit membutuhkan proses mengkomunikasikan kebudayaan kepada masyarakat yang baru, ${ }^{4}$ agar masyarakat atau khalayak ramai dapat mengenal dan memahami produk yang dimilikinya, atau dikenal dengan istilah sosialisasi. Langkah-langkah terkait medote sosialisasi produk dapat dilakukan melalui pengenalan seperti melakukan kunjungan formal maupun nonformal, mengadakan pelatihanpelatihan, seminar-semina, dan lain-lain ${ }^{5}$ sebagaimana yang telah dilakukan Rumah Zakat, sebagai lembaga yang konsern dalam pengelolaan zakat, infak, di tengah-tengah masyarakat dalam memperkenalkan produknya terutama produk penghimpunan dan penyaluran Zakat, infaq, dan sedekah.

Berdasarkan uraian tersebut di atas, maka penulis tertarik untuk meneliti implementasi sosialisasi produk yang telah diterapkan oleh Lembaga Amil Zakat Nasional (LAZNAS) Rumah Zakat Cabang Makassar dalam mensosialisasikan produknya dan kendala-kendala yang dihadapi dalam pelaksanaan sosialiasinya.

Adapun tujuan penelitian ini yakni untuk mengetahui implementasi sosialisai produk yang dilakukan oleh Rumah Zakat Cabang Makassar dan kendala-kendala yang dihadapi dalam menjalankan implementasi sosialiasi produk pada Rumah Zakat Cabang Makassar.

\section{METODE PENELITIAN}

Penelitian ini merupakan penelitian kualitatif deskriptif, dengan menitikberatkan pada hasil pengumpulan data dari informan yang ditentukan yang secara deskriptif menjelaskan keadaan-keadaan yang berkaitan dengan studi lapangan tersebut. Penelitian kualitatif menggunakan berbagai macam saran guna mempermudah peneliti dalam mendapat data yang valid dan obyektif. Pelaksanaan jenis penelitian ini terjadi secara alamiah, apa adanya, dalam situasi normal yang tidak dimanipulasi keadaan dan kondisinya atau menekankan pada deskripsi alami. ${ }^{6}$

Pendekatan yang digunakan adalah pendekatan sosial ekononomi normatif, dan teologi, yang akan melihat dari sisi sosial kemasyarakatan dalam penerapan

${ }^{3}$ Amir, ST., Branch Manager Rumah Zakat Cabang Makassar: Laporan Keuangan LAZNAS Rumah Zakat Cabang Makassar Tahun 2014-2015 (Wawancara oleh penulis di Kantor RZ Cabang Makassar J1. Sunu no. 32B Makassar pada tanggal 02 Februari 2016).

${ }^{4}$ J. Supranto, Metode Riset dan Aplikasinya dalam Pemasaran (Jakarta: Fakultas Ekonomi Universitas Indonesia; 1986), h. 38.

5. Ibid., h. 70 .

${ }^{6}$ Lexy J. Moleong, Metodologi Penelitian Kualitatif (Bandung: PT. Rosda Karya; 2005), h. 26. 
sosialisasi produk oleh Rumah Zakat, dengan memadukan kajian tinjauan teoritis dan kajian dalil dalam penerapan sosialisasi produk.

Sumber datanya terdiri dari data primer dan data sekunder. Data primer adalah data yang diperoleh langsung dari sumbernya, diamati dan dicatat untuk pertama kalinya. Kata-kata dan tindakan subyek yang akan diamati atau yang diwawancarai merupakan sumber utama. Hal ini berkaitan dengan penilitian yang akan diteliti. Maka data primer yang dimaksud merupakan data utama ${ }^{7}$ menyangkut "Implementasi Sosialisasi Produk pada Rumah Zakat Cabang Makassar". Melalui wawancara dan observasi terhadap informan yang akan diteliti, yakni berjumlah enam (6) orang, diantaranya: A (Branc Manager Rumah Zakat Cabang Makassar), F (Financial Rumah Zakat Cabang Makassar), IS (Super Infaq Consultant/SICO Rumah Zakat Cabang Makassar), T (SPMO/Indonesia Juara Foundation Rumah Zakat Cabang Makassar), SM (Healt Care Officer/HCO Rumah Zakat Cabang Makassar), dan R (Koordinator Komite Relawan Nusantara/KRN Rumah Zakat Cabang Makassar).

Data sekunder yaitu data yang digunakan oleh peneliti, adapun kegunaan data sekunder adalah memberikan petunjuk kepada peneliti kearah mana peneliti akan melangkah lebih lanjut. Data sekunder yang dipakai dalam penelitian ini adalah data kepustakaan dan yang berkaitan denganya seperti buku, referensi-referensi, serta materi-materi tertulis yang relevan dengan tujuan penelitian ${ }^{8}$ dalam hal ini adalah Implementasi Sosialisasi Produk pada Rumah Zakat Cabang Makassar.

Adapun metode pengumpulan data yang akan dilakukan adalah pengumpulan data yang dilakukan secara langsung di lapangan. ${ }^{9}$ Melalui mekanisme Observasi (pengamatan/peninjauan), Interview (wawancara), dan Telaah Dokumen. Kemudian diolah dengan metode analisis data interaktif. melalui tiga tahap, reduksi data (data reduction) diartikan sebagai peoses pemilihan, pemusatan perhatian, penyederhanaan, yang muncul dari catatan tulisan sewaktu dilapangan (Field Note), dimana reduksi data berlangsung secara terus-menerus selama penelitian kualitatif berlangsung; Penyajian data (data display) merupakan sekumpulan informasi yang tesusun kemudian memberi kemungkinan adanya penarikan kesimpulan dan pengambilan keputusan terkait penelitian yang diteliti; dan Verifikasi (verification) atau tahap penarikan kesimpulan merupakan sebagian dari suatu kegiatan dan konfigurasi yang utuh. Dimana peneliti dapat menarik kesimpulan dari hasil verifikasi tersebut. ${ }^{10}$

\section{${ }^{7}$ Ibid., h. 18.}

${ }^{8}$ Ibid., h. 17.

${ }^{9}$ Dedy Mulyana, Metodologi Penelitian Kualitatif: Paradigma Baru Ilmu Komunikasi dan Ilmu Sosial Lainnya (Bandung: PT. Remaja Rosdakarya, 2004), 150.

10 Anis Fuad dan Kandung Sapto Nugroho, Panduan Praktis Penelitian Kualitatif (Yogyakarta: Garaha Ilmu; 2014), Cetakan Ke I, h. 63-64. 


\section{PEMBAHASAN}

\section{A. Hasil Penelitian}

Setelah dilakukan penelitian di Rumah Zakat Cabang Makassar, diperoleh data hasil penelitian sebagai berikut.

\section{Bentuk-Bentuk Sosialisasi Produk Rumah Zakat Cabang Makassar}

Menurut Gibson, sosialisasi sebagai suatu aktivitas yang dilakukan oleh organisasi untuk mengintegrasikan tujuan organisasional maupun individual. ${ }^{11} \mathrm{Hal}$ inilah yang dilakukan Lembaga Amil Zakat Nasional (LAZNAS) Rumah Zakat Cabang Makassar dalam mengintegrasikan sosialisasi sebagai lembaga filantropi. Selanjutnya Rumah Zakat Cabang Makassar mempunyai beberapa bentuk implementasi dalam mensosialisasikan produknya. Yakni kunjungan formal, kunjungan non formal, Pelatihan-pelatihan dan Seminar-seminar sebagaimana yang telah disebutkan pada pembahasan sebelumnya.

a. Kunjungan formal

Kunjungan formal ${ }^{12}$ Rumah Zakat Cabang Makassar adalah agenda-agenda dalam rangka mensosialisasikan produk Rumah Zakat serta berusaha menjalin hubungan bilateral kerjasama secara formal antara individu-individu, kelompokkelompok atau organisasi-organisasi dan instansi-insatansi untuk mencapai suatu tugas atau tujuan tertentu baik yang berada di Indonesia maupun diluar negeri. Hal ini diwujudkan Rumah Zakat sesuai visi Rumah Zakat sebagai lembaga filantropi yang menjunjung tinggi nilai-nilai kerjasama berbasis sosial. Lembaga dan instansi/organisasi yang menjadi mitra ${ }^{13}$ Rumah Zakat secara nasional dapat dilihat pada tabel berikut:

Tabel 1.

Lembaga Yang menjadi mitra Rumah Zakat secara Nasional.

\begin{tabular}{|c|l|c|l|}
\hline No. & \multicolumn{1}{|c|}{ Nama Lembaga } & No. & \multicolumn{1}{|c|}{ Nama Lembaga } \\
\hline 1 & \multicolumn{1}{|c|}{2} & 3 & \multicolumn{1}{|c|}{4} \\
\hline 1. & iB Mega Syariah & 10. & PT. Pelabuhan Indonesia II. \\
\hline 2. & PT. Adira Insurance & 11. & PT. Sriboga Flour Mill \\
\hline 3. & $\begin{array}{l}\text { SEAHUM (South East Asia } \\
\text { Hummanitarian Committee.) }\end{array}$ & 12. & Bhakestra. \\
\hline 4. & PT. Skye Sab Indonesia. & 13. & $\begin{array}{l}\text { GRES! (Gerakan Ekonomi } \\
\text { Syaraiah) }\end{array}$ \\
\hline 5. & PT. Telkomsel. & 14. & PT. PLN (Persero) P3B \\
\hline
\end{tabular}

${ }^{11}$ Gibson JL., Ivancevich JM., dan Donnelly JH., jr., Organizations: Behavior, Structure and Process (Boston, 1994), Terj. Irwin, Organisasi: Perilaku, Struktur dan Proses (Jakarta: Publishing), edisi ke-8., h. 229.

12 Kunjungan Formal Rumah Zakat merupakan bentuk implementasi dalam rangka mensosialisasikan produk hingga kinerja Rumah Zakat dengan beberapa lembaga hingga tercipta mitra corporation (Corporation Strategy) dengan lembaga-lembaga tersebut (Pen.-).

${ }^{13}$ Mitra merupakan patner kerjasama dalam rangka mempermudah penerimaan dana zakat serta menyalurkanya kepada mustahik yang menjadi binaan Rumah Zakat atau sering dikenal dengan ICD/Integrated Community Developmen (Pen.-). 


\begin{tabular}{|l|l|l|l|}
\hline & & & Jawa Bali. \\
\hline 6. & PT. Astra Honda Motor & 15. & $\begin{array}{l}\text { Jakarta International } \\
\text { Container Terminal }\end{array}$ \\
\hline 7. & $\begin{array}{l}\text { Tower Bersama } \\
\text { Infrastructure, Tbk. }\end{array}$ & 16. & $\begin{array}{l}\text { PT. Hariff Daya Tunggal } \\
\text { Engineering. }\end{array}$ \\
\hline 8. & $\begin{array}{l}\text { PT. Pertamina EP Field } \\
\text { Rantau }\end{array}$ & 17. & $\begin{array}{l}\text { PT. Pertamina EP Regional } \\
\text { Jawa }\end{array}$ \\
\hline 9. & $\begin{array}{l}\text { Yayasan Pendidikan } \\
\text { Telkom }\end{array}$ & 18. & PT. Perusahaan Gas Negara \\
\hline \\
$\begin{array}{l}\text { (Sumber data: Data primer Lembaga Mitra Rumah Zakat Cabang Makassar secara Nasional } \\
\text { tahun 2014) }\end{array}$
\end{tabular}

Tabel 2.

Mitra-Mitra LAZNAZ Rumah Zakat dengan Bank secara Nasional.

\begin{tabular}{|c|c|c|}
\hline No. & Nama Lembaga & $\begin{array}{c}\text { Nomor Rekening } \\
\text { (Atas nama Yayasan RZ Indonesia) }\end{array}$ \\
\hline 1 & 2 & 3 \\
\hline 1. & Bank Mandiri & 1320004819745 \\
\hline 2. & Bank Muamalat & 1010082208 \\
\hline 3. & Bank BCA & 0943016001 \\
\hline 4. & Bank BNI Syariah & 1555555589 \\
\hline 5. & Danamon Syariah & 78958808 \\
\hline 6. & Bank bjb Syariah & 0010101005735 \\
\hline 7. & Bank Mega Syariah & 1000000270 \\
\hline 8. & Bank Bukopin Syariah & 8801111042 \\
\hline 9. & Bank BTN Syariah & 7021001555 \\
\hline 10. & Bank Bii Syariah & 2700005599 \\
\hline 11. & CIMB Niaga Syariah & 5200100131005 \\
\hline 12. & Bank BRI & 114101000127304 \\
\hline 13. & OCBC NISP Syariah & 247800009000 \\
\hline 14. & Bank BRI Syariah & 1000859172 \\
\hline 15. & Bank DKI Syariah & 7017007000 \\
\hline 16. & Permata Bank Syariah & 3771001555 \\
\hline 17. & Bank BNI & 1555155581 \\
\hline 18. & Bank Mandiri Syariah & 7015518248 \\
\hline 19. & Bank Mandiri Syariah & 7015533441 \\
\hline 1 Rek. Dollar) & \\
\hline
\end{tabular}

(Sumber data: Data primer, Lembaga Keuangan Bank Mitra Rumah Zakat Cabang Makassar secara Nasional tahun 2014)

Adapun lembaga-lembaga yang telah menjadi mitra kerjasama Rumah Zakat Cabang Makassar ${ }^{14}$ adalah:

\footnotetext{
${ }^{14}$ Lembaga-lembaga yang menjadi mitra Rumah Zakat Cabang Makassar berbeda dengan Rumah Zakat diberbagai daerah di Indonesia pada umumnya baik pusat maupun kantor cabang. Hal ini
} 
Tabel 3.

Lembaga-Lembaga Mitra Ruma Zakat Cabang Makassar.

\begin{tabular}{|l|l|l|l|}
\hline No. & \multicolumn{1}{|c|}{ Nama Mitra } & \multicolumn{1}{c|}{ No. } & \multicolumn{1}{c|}{ Nama Mitra } \\
\hline 1. & JILC & 7. & YBM BRI \\
\hline 2. & LAZ Telkom & 8. & Bank BNI Syariah Mikro \\
\hline 3. & $\begin{array}{l}\text { MT (Majelis Ta'lim) } \\
\text { Telkom }\end{array}$ & 9. & Bank PERMATA \\
\hline 4. & SKI Indosat & 10. & MESJID KANWIL PAJAK \\
\hline 5. & Bank BTN & 11. & $\begin{array}{l}\text { PT. Masaji Tatanan } \\
\text { Container }\end{array}$ \\
\hline 6. & Bank BJB & 12. & LOTTE Mart. \\
\hline \multicolumn{2}{|l|}{ (Sumber data: Data primer Lembaga Mitra Rumah Zakat Cabang Makassar tahun 2014) }
\end{tabular}

b. Kunjungan Non Formal

Selain beberapa kunjungan formal diatas yang kemudian terjalin bentuk kerjasama (Mitra Coorporation), Rumah Zakat Cabang Makassar mempunyai kunjungan non-formal ${ }^{15}$ dalam rangka mengkomunikasikan atau menyampaikan informasi akan produk-produknya kepada masyarakat secara luas. Bentuk implementasi sosialisasi produk Rumah Zakat ini, kebanyakan melalui media sosial (SOSMED) baik secara fisik maupun non fisik. ${ }^{16}$

Seiring meningkatnya teknologi sekarang ini, aplikasi media merupakan bagian terpenting dalam sebuah sosialisasi karena media bisa langsung berinteraksi dengan masyarakat. Untuk itu, sangat dibutuhkan kreativitas suatu organisasi dalam menggunakan media untuk mensosialisasikan produk kepada publik atau masyarakat.

Sarana media yang sering digunakan dalam implementasi sosialisasi produk baik secara fisik seperti spanduk, baligho, poster, leaflet, x-banner. Sedangkan media secara non-fisik seperti iklan dan jejaring sosial (Social network) lainya. ${ }^{17}$

c. Pelatihan

Berkaitan dengan pelaksanaan sosialisasi, Rumah Zakat Cabang Makassar juga mengadakan pelatihan-pelatihan guna memperkokoh kredibilitas sebagai lembaga filantropi di Indonesia dimata masyarakat. Jenis pelatihan yang diberikan

di pengaruhi oleh kebijakan atau strategi masing-masing kantor cabang di seluruh Indonesia dalam bermitra (Pen.-).

${ }^{15}$ Kunjungan Non Formal merupakan sarana implementasi sosialisasi Rumah Zakat kepada masyarakat yang menggunakan sarana media teknologi untuk menginformasikan produk-produk Rumah Zakat (Pen.-).

${ }^{16}$ Yang dimaksud dengan Sosial Media (SOSMED) secara fisik atau biasa dikenal dengan media cetak adalah media yang dapat dicetak. Sedangkan media secara Non-Fisik atau sering dikenal dengan sebutan media audio visual/media internet adalah media yang yang menggunakan elektronik (Pen.-).

${ }^{17}$ Jenis-jenis implementasi Rumah Zakat Cabang Makassar dalam melakukan sosialisasi yakni hanya pada spanduk, poster, pamphlet serta x-banner dan media sosial seperti tweeter dan facebook dan Instalgram(Pen.-). 
oleh Rumah Zakat kepada masyarakat antara lain pembinaan berupa pelatihan cara membuat goodiebag dari bahan kertas kado, kegiatan penyuluhan Cuci Tangan Pakai Sabun (CTPS), dilanjutkan dengan senam cuci tangan, dan nonton bersama video edukasi islami dan membagikan beberapa doorprize.

d. Seminar

Seminar juga merupakan sarana yang banyak dilakukan oleh organisasiorganisasi baik organisasi laba maupun nirlaba/sosial. Namun kegiatan ini belum pernah dilakukan oleh Rumah Zakat Cabang Makassar sebagaimana yang telah diungkapkan oleh Amir selaku Branch Manager Rumah Zakat Cabang Makassar, sejak berdiri pada tahun 2008 hingga saat ini belum sama sekali melakukan seminar sebagai wadah sosialisasi kepada masyarakat. Beliau mengungkapkan, hingga saat ini (2008-2016) belum ada kegiatan seperti seminar yang dilakukan ${ }^{18}$ Rumah Zakat Cabang Makassar sebagai sarana sosialisasi program zakat di Makassar. Selanjutnya kami hanya fokus pada pembianaan wilayah ICD (Integrated Community Development) yang telah kami bina. ${ }^{19}$

\section{Kendala-Kendala Yang dihadapi dalam Implementasi Sosialisasi Produk Rumah Zakat Cabang Makassar}

Secara aplikatif, kendala-kendala implementasi Rumah Zakat Cabang Makassar dalam mensosialisasikan produk-produknya terbagi dalam dua kategori yakni kendala secara Internal dan secara eksternal.

\section{a. Kendala Internal Rumah Zakat Cabang Makassar}

Pada tahap implementasinya, kendala internal Rumah Zakat Cabang Makassar dalam melakukan sosialisasi adalah faktor keuangan. Menurut Amir, Rumah Zakat Cabang Makassar tidak mempunyai kendala maupun hambatan sama sekali dalam melakukan sosialisasi. ${ }^{20}$

Kendala-kendala internal Ruma Zakat Cabang Makassar lainnya hanya terletak pada dorongan Rumah Zakat terhadap masyarakat/member agar perlu ditingkatkan serta motivasi kepada member Rumah Zakat agar terus diperbaharui. Hal ini disampaikan Salmiah Made selaku Health Care Officer (HCO) Rumah Zakat Cabang Makassar. Menurut hemat beliau: tidak ada kendala-kendala secara signifikan hanya semangat member (Muzakki) harus diperbaharui secara simultan. ${ }^{21}$

Secara umum segalah bentuk permasalahan dapat teratasi dengan baik. Jika pun terdapat masalah, paling tidak hanya pada masalah teknis lapangan saja. Hal ini

${ }^{18}$ Amir, ST., Branch Manager: Seminar RZ Cabang Makassar (Wawancara oleh penulis di Kantor RZ Cabang Makassar Jl. Sunu no. 32B Makassar pada tanggal 1 Desember 2015).

${ }^{19}$ Ibid.

${ }^{20}$ Amir, ST., Branch Manager Rumah Zakat Cabang Makassar: Kendala Internal Sosialisasi Rumah Zakat Cabang Makassar (Wawancara oleh penulis di Kantor Rumah Zakat Cabang Makassar J1. Sunu no. 32B Makassar, yang dikelola pada tanggal 09 November 2015).

${ }^{21}$ Salmiah Made, Cita Sehat Foundation: Kendala Internal Soialisasi Rumah Zakat Cabang Makassar (Wawancara oleh Penulis di Kantor Rumah Zakat Cabang Makassar J1. Sunu no. 32B Makassar, yang dikelola pada tanggal 29 Oktober 2015). 
disampaikan oleh Pak Taufik di tengah wawancara tentang kendala-kendala sosialisasi Rumah Zakat pada bidang Relawan (KRN). Menurut hemat beliu:

Kendala-kendala terkait sosialisasi Rumah Zakat biasanya hanya terdapat pada kekurangan SDM ditingkat relawan itu sendiri mengenai turun langsung ke lapangan. ${ }^{22}$ Senada dengan Taufik, Pak Ramli selaku Coordinator Relawan Cabang Makassar juga mengungkapkan:

Jadi secara umum, kegiatan-kegiatan Relawan menyangkut sosialisasi program Rumah Zakat biasanya terkendala pada bertabrakannya waktu kuliah atau agenda kampus lainya dengan agenda KRN Rumah Zakat Cabang Makassar. Hal ini dikarenakan anggota relawan itu sendiri yang sebagian besar beranggotakan anak muda dan berstatus mahasiswa. ${ }^{23}$

\section{b. Kendala Eksternal Rumah Zakat Cabang Makassar}

Secara aplikatif, kendala atau hambatan yang dihadapi Rumah Zakat Cabang Makassar dalam mensosialsasikan produk-produknya terletak pada kesadaran masyarakat Makassar yang belum sepenuhnya menyadari pentingnya mengeluarkan sebagian hartanya, khususnya zakat dalam membangun pondasi ekonomi masyarakat agar lebih mandiri secara financial serta dapat mencukupi kebutuhan masyarakat tidak mampu pada khususnya. Hal ini disampaikan oleh Amir, selaku Branch Manager Ruma Zakat Cabang Makassar. Menurutnya, kendala terbesar secara eksternal Rumah Zakat Cabang Makassar terletak pada kesadaran masyarakat dalam berzakat. Selanjutnya, beliau mengungkapkan bahwa tidak ada kendala secara internal dalam melakukan sosialisasi dalam bentuk program-progran atau produk Rrumah Zakat Cabang Makassar dikarenakan hal-hal semacam ini (sosialisasi) sudah menjadi kinerja Rumah Zakat untuk menyampaikan serta mengingatkan kepada masyarakat untuk berzakat. ${ }^{24}$

Sejalan dengan Amir, Menurut Kurniawati, kendala-kendala eksternal Lembaga atau Organisasi Pengumpul Zakat (OPZ) terletak pada:

a. Terbatasnya pengetahuan masyarakat yang berkaitan dengan ibadah zakat,

b. Konsepsi zakat yang masih dirasa terlalu sederhana dan tradisional. Hingga akhirnya dalam pelaksanaannya pun masih sangat sederhana, yaitu cukup dibagikan langsung sendiri kepada lingkungannya atau kepada kyai yang disenangi,

c. Sifat manusia yang kikir. Sehingga jika kekayaan itu diperoleh atas jerih payah dalam memeras otak, keringat dan kemampuannya sendiri, sehingga makin beratlah orang tersebut untuk mengeluarkan zakatnya,

\footnotetext{
${ }^{22}$ Ramli, Koordinator Komite Relawan Nusantara: Kendala Internal Sosialisasi Rumah Zakat Cabang Makassar (Wawancara oleh penulis di Kantor Rumah Zakat Cabang Makassar Jl. Sunu no. 32B Makassar yang dikelola pada tanggal 20 September 2015).

${ }^{23}$ Ibid.

${ }^{24}$ Amir, ST., Branch Manager Rumah Zakat Cabang Makassar: Kendala Eksternal Sosialisasi Rumah Zakat Cabang Makassar (Wawancara oleh penulis di Kantor Rumah Zakat Cabang Makassar Jl. Sunu no. 32B Makassar, yang dikelola pada tanggal 18 September 2015).
} 
d. Kepercayaan muzakki, dimana banyak muzaki yang masih khawatir zakat yang diserahkannya hanya dipergunakan oleh amilnya. ${ }^{25}$

Beberapa kendala eksternal diatas mengindikasikan bahwa sosialisasi merupakan sarana paling penting dalam tubuh Lembaga Pengumpul Zakat (OPZ) atau LAZNAS. Hal ini dijelaskan oleh salah satu dosen IPB Irfan Syauqi Beik, menurutnya, problem mendasar tidak optimalnya pengelolaan zakat sampai hari ini karena lemahnya sosialisasi dan penyadaran terhadap masyarakat. ${ }^{26}$ Selanjutnya lemahnya sosialisasi akhirnya akan berdampak pada ketidakpercayaan masyarakat terhadap lembaga-lembaga amil zakat yang sekarang mencoba mengelola zakat secara profesional. ${ }^{27}$

\section{B. Pembahasan dan Analisis Data Penelitian.}

Zakat merupakan rukun islam ketiga dalam hukum Islam, yang mempunyai potensi kebaikan yang cukup besar dibalik perintah untuk wajib berzakat bagi umat Islam. ${ }^{28}$ Selanjutnya, dengan zakat masyarakat dapat menyucikan diri sekaligus dapat membersihkan harta yang didapatkan para pembayar zakat (muzakki) dan harta yang dizakatka akan dipelihara oleh Allah swt., memperoleh keberkahan dan kesucian serta mendapat perlindungan dari Allah swt. ${ }^{29}$ Sedangkan jika dilihat dari aspek sosial kemasyarakatan, maka keberadaan dana zakat dapat menjadi soslusi dari tekanan ekonomi yang dialami oleh orang-orang/masyarakat kurang mampu yang dizakati (mustahik) tersebut.

Urgensi Lembaga Pengelolaan Zakat (LPZ) di Indonesia pada tahap pelaksanaannya muncul sebagai sarana pemberdayaan masyarakat yang mengalami kesenjangan antara potensi dan realita tersebut (kemiskinan, kebodohan, pemberdayaan dan kesejahteraan). Untuk itu, kesenjangan yang ada harus dikelolah dengan baik jika ingin menjadikan dana zakat sebagai soslusi kesenjangan sosial ekonomi yang ada di masyarakat.

Jika dicermati lebih mendalam, sosialisasi dan pemanfaatan media sosialisasi sudah sangat menjadi kebutuhan apalagi organisasi pengumpul zakat. Dan beberapa faktor yang menjadi kebutuhan bagi Lembaga Amil Zakat terhadap sosialisasi tersebut adalah:

a.) Sosialisasi sebagai intermediary (jembatan) antara masyarakat dan pelaku organisasi pengumpul zakat,

${ }^{25}$ Kurniawati, Kedermawanan Kaum Muslimin (Jakarta: Piramedia, 2004), Cetakan II, hal. 28.

${ }^{26}$ Irfan Syauqi Beik, Masa Depan Zakat di Indonesia (Ripublika, 2 September 2009).

${ }^{27}$ Ibid.

${ }^{28}$ Zakat untuk pertama kalinya turun di Makkah namun hanya bersifat anjuran. Tetapi zakat itu sendiri diwajibkan di Madinah, tahun 2 Hijriya sekaligus penentuan nisab dan kadar tertentu untuk zakat tersebut. Lihat Prof. DR. Yusuf Qaradhawi, Fiqhuz Zakat (Libanon: Muassasah ar-Risalah; 1973), Cet. Ke-2. Terj. Dr. salman Harun, Dkk., Hukum Zakat (Jakarta: PT. Pustaka Lintera AntarNusa; 1988), Cet. Ke-12, h. 61.

${ }^{29}$ Hasbi Ash-Shiddieqy, Pedoman Zakat (Semarang: PT. Pustaka Rizki Putra; April 2010), Cet. Ke 2, Edisi Ke 3, h. 7. 
b.) Sosialisasi dapat bertindak sebagai wadah edukasi bagi masyarakat akan pentingnya dana zakat,

c.) Sosialisasi merupakan salah satu faktor serta sarana pendorong meningkatnya kebutuhan masyarakat terhadap perintah agama untuk berzakat,

d.) Sosialisasi dapat menjadi sarana motivasi bagi orang lain untuk berbuat kebaikan dan lebih peduli terhadap masalah sosial,

e.) Sosialisasi dapat meningkatkan produktivitas layanan lembaga amil zakat,

f.) Sosialisasi dapat mempermudah masyarakat (calon muzakki) untuk mengenal lebih jauh akan tujuan terbentuknya organisasi atau Lembaga Amil Zakat beserta program-program yang diusungnya. ${ }^{30}$

Berdasarkan hal tersebut, jelaslah bahwa sosialisasi merupakan faktor penting yang menjadi roda keberlangsungan bagi Lembaga Amil Zakat yang secara praktik dipercayai sebagai wadah pemberdayaan dan terciptanya keseimbangan sosial bagi masyarakat.

\section{Strategi Sosialisasi LAZNAS Rumah Zakat Cabang Makassar.}

Seperti halnya sebuah perusahaan, Lembaga Pengelola Zakat pun mesti memiliki strategi dalam merebut perhatian dari pasar donatur, dalam hal ini LPZ telah memiliki pasar tersendiri yaitu, para wajib zakat, dan mempertahankan loyalitas mereka. Lebih dari itu LPZ juga bertanggung jawab untuk menumbuhkan kesadaran para wajib zakat agar membayarkan zakat mereka. Hal ini dipandang sangat penting untuk kontinuitas dan upaya pemberdayaan masyarakat yang mereka lakukan. Untuk itu perlu bagi LPZ membangun sebuah strategi untuk melaksanakan tugas-tugas tersebut dengan baik.

Kebijakan strategi terkait implementasi sosialisasi produk/programnya yakni yang dilakukan antara lain:

a. Pola membangun mitra

Rumah Zakat telah banyak dipercaya oleh mitra-mitra yang telah menjalani kerjasama denganya baik perseorangan, lembaga atau perusahaan (nasional dan daerah). Tercatat pada tahun 2014 hingga 2015 LAZNAS Rumah Zakat Cabang Makassar telah bekerja sama dengan kurang lebih 28 perusahaan-perusahaan yang ada di Kota Makassar. ${ }^{31} \mathrm{Hal}$ ini disinggung juga oleh Norton dengan istilah Corporate Donors sebagai salah satau strategi penggalangan dana bagi perusahaan nirlaba $^{32}$ seperti L/OPZ.

${ }^{30}$ Sosialisasi juga termasuk sarana untuk membangun Kepercayaan antara pemberi dan penerima Zakat. (Pen.-). Lihat kitab Daurul Zakah, Fi 'Illaj al-Musykilaat al-Iqtishaadiyah yang ditulis oleh Dr. Yusuf Qaradhawi. Terj. Sari Narulita, Lc., Spektrum Zakat dalam Membangun Ekonomi Kerakyatan (Jakarta: Zikrul Hakim; 2005), Cet.-1, h. 152.

${ }^{31}$ Lihat mitra-mitra Rumah Zakat Cabang Makassar termasuk Bank dan Lembaga lainnya pada pembahasan sebelumnya (Pen.-).

${ }^{32}$ M. Norton, Menggalang Dana: Penuntun bagi Lembaga Swadaya Masyarakat dan Organisasi Sukarela di Negara-Negara Selatan (Jakarta: Yayasan Obor Indonesia, 2002), Edisi Ke- I. h. 51. 
Strategi dengan cara membangun mitra merupakan cara lain agar memudahkan pengumpulan dana zakat dari para karyawan dari kantor yang dimitrai Rumah Zakat Cabang Makassar tersebut maupun bagi orang-orang yang mempunyai dana lebih untuk dizakati namun enggan pergi ke kantor LPZ secara langsung.

Di dalam konsep community development, paling tidak ada tiga pertukaran manfaat dari kemitraan antara LAZ dan perusahaan yakni:

1.) Pihak perusahaan memiliki ruang agar dapat melakukan aktivitas membangun masyarakat bersama-sama dengan LAZ.

2.) LAZ dapat mengembangkan diri dan mengaplikasikan keahliannya melalui program-program yang digulirkan.

3.) Masyarakat sebagai penerima program berpeluang untuk berpartisipasi aktif dalam memberdayakan diri sendiri. Singkatnya, pola kemitraan ini memiliki prinsip hubungan yang saling menguntungkan (simbiosis mutualisme).

Sebagai contoh dari pola membangun kemitraan yang dilakukan oleh LAZNAS Rumah Zakat Cabang Makassar adalah MT Telkomsel dan BNI Syariah Mikro Sulawesi Selatan. ${ }^{33}$

b. Memperluas Jaringan Komunikasi (IT)

Selain membangun mitra, strategi lain yang bisa di dilihat dari Rumah Zakat Cabang Makassar dalam mempercepat pelaksanaan sosialisasi kepada masyarakat adalah memperluas jaringan Komunikasi.

Pemanfaatan jaringan komunikasi melalui media teknologi sekarang ini sangat membantu dalam menyampaikan informasi terkait akuntabilitas laporan keuangan Lembaga Pengumpul Zakat kepada masyarakat. Pemberian informasi yang akurat, lengkap dan cepat akan mempengaruhi kualitas pengambilan keputusan bagi Lembaga Pengumpul Zakat (LPZ) secara internal dan minat masyarakat untuk mau berzakat di Rumah Zakat Cabang Makassar.

Penggunaan IT dan Komunikasi pada LAZNAS Rumah Zakat Cabang Makassar cukup di acungi jempol. Ditahun 2015 terdapat bebrapa perluasan jaringan komunikasi untuk mempermudah masyarakat tingkat ekonomi menengah untuk menyalurkan dana zakat melalui:

1.) Paypal: Dengan metode online purchase, Paypal menjadi salah satu pilihan kemudahan dalam berzakat. Dengan klik www.rumahzakat.org/paypal.html. untuk berbagi secara online.

2.) E-Banking dan Mobile Banking: menggunakan jasa perbankan di internet dengan mengakses website www.rumahzakat.org dan memilih menu ebanking dari bank kepercayaan.

3.) Zakat Via ATM Manfaatkan kemudahan berzakat via ATM. Anda juga bisa mentransfer zakat dari bank kepercayaan anda kepada rekening kami.

4.) Zakat di Kantor Pos Kunjungi 4500 jaringan kantor pos di seluruh Indonesia untuk membayar zakat ke Rumah Zakat.

${ }^{33}$ Lihat kegiatan MT Telkomsel dan BNI Syariah Mikro Sulsel pada Lampiran Yang telah kami (penulis) cantumkan (Pen.-). 
5.) Zakat di LOTTEMart: Kini sambil berbelanja di seluruh jaringan LOTTEMart di Indonesia anda dapat berzakat ke Rumah Zakat.

6.) Zakat di Skye Kini anda bisa membayar zakat sambil berbelanja. Caranya anda bisa mengakses www.skye.co.id/rumahzakat dari ponsel anda.

7.) Ayo ke Bank, Kini anda dapat berdonasi melalui teller diseluruh Bank yang ada di Indonesia. ${ }^{34}$

Selain pemanfaatan rekening bank sebagai sarana yang memudahkan muzakki menyalurkan dana zakatnya, Eri Sadewo menambahkan satu hal yang berkaitan dengan pemanfaatan jaringan komunikasi dan informasi teknologi. Yakni, Layanan Donatur atau Customer Care. Menurut Sadewo, fungsi dan tugas utama layanan donatur adalah mengatasi persoalan yang muncul antara LPZ dan Muzakki. Diantaranya:

1.) data donatur, data donatur harus didokumentasikan,

2.) keluhan, layan donatur harus cermat dalam mendata keluhan dari donatur, keluhan ini harus disusun, dikompilasi, dan dianalisa,

3.) Follow up keluhan, mengatakan akan ditangani oleh yang berwenang sebagai jawaban atas keluhan merupakan jawaban yang professional, namun bila hanya sekedar jawaban tanpa follow up ini merupakan kebohongan publik. ${ }^{35}$

c. Menggunakan Media Promosi

Setelah membangun mitra kemudian memperluas dengan jaringan komunikasi kepada masyarakat, LAZNAS Rumah Zakat Cabang Makassar juga menggunakan metode-metode promosi agar lebih intensif dan semakin dekat dengan hati masyarakat. Hal ini dilakukan agar tetap terjaga komunikasi serta konsistensi Rumah Zakat Cabang Makassar sebagai Lembaga Filantropi di Indonesia.

Promosi pada Lembaga Pengumpul Zakat (LPZ) merupakan sarana komunikasi atau sistem penyebaran informasi terkait program, produk jasa kepada masyarakat atau kegiatan "adaptasi langsung" untuk mempengaruhi, membujuk dan mengingatkan masyarakat terhadap pentingnya dana zakat untuk kesejahteraan ummat.

Disadari atau tidak pada LAZNAS Rumah Zakat Cabang Makassar telah melakukan strategi-strategi promosi sebagai sarana sosialisasi program (produk) seperti Mass Selling. Mass Selling sendiri terbagi dua pokok utama yakni, periklanan (Advertising) dan publisitas (Publicity).

1.) Periklanan (Adversiting)

Adversiting merupakan promosi yang dilakukan dalam bentuk tayangan atau gambar atau kata-kata yang tertuang dalam spanduk, brosur, leaflet, billboard, poster, koran, majalah, televisi atau radio. ${ }^{36}$

${ }^{34}$ Lihat Rekening Bank yang menjadi Mitra Rumah Zakat di Seluruh Indonesia Pada pembahasan Sebelumnya (Pen.-).

\footnotetext{
${ }^{35}$ Eri Sadewo, Loc. Cit., h. 198.

${ }^{36}$ Kementerian Pendidikan Nasional, Loc. Cit., h. 25.
} 
Akan tetapi, adversiting yang dianggap penting dan digunakan pada LAZNAS Rumah Zakat Cabang Makassar adalah Spanduk, Brosur, Leaflet atau pamflet dan X-Banner. Salah satu contoh iklan yang digunakan pada spanduk Rumah Zakat Cabang Makassar pada kegiatan Upgrading Korwil dan Mentor Makassar pada tanggal 21 Maret 2015. Di spanduk itu, Rumah Zakat Cabang Makassar mengusung tema "Menjadi Idola dan Menginspirasi Dunia".

Sekilas, memang terlihat biasa-biasa saja pada spanduk tersebut. Namun konten pada tema yang diusung oleh Rumah Zakat Cabang Makassar tersebut yang mempunyai makna bahwa dengan menjadi idola dengan kecerdasan sosial, maka seseorang ataupun siapa saja akan mampu menginspirasi dunia.

2.) Publisitas (Publicity)

Publisitas (publicity) bisa dikatakan sebagai media promosi yang dilakukan untuk meningkatkan citra Organisasi Pengumpul Zakat (OPZ) kepada masyarakat melalui kegiatan-kegiatan sponsorship terhadap suatu kegiatan amal atau sosial. Atau menurut Tjiptono, Publisitas (Publicity) adalah sejumlah informasi tentang seseorang, barang, atau organisasi yang disebarluaskan ke masyarakat melalui media tanpa dipungut biaya, atau tanpa pengawasan dari sponsor. $^{37}$

Publisitas sering digunakan oleh media untuk menyebarluaskan kegiatankegiatan yang diadakan oleh Rumah Zakat Cabang Makassar di daerah-daerah tertentu. Contoh salah satunya penyaluran bantuan kepada korban kebakaran di Kelurahan Lembo, Kecamatan Tallo, Makassar, yang dimuat oleh Kabar Sulsel ${ }^{38}$

Berita diatas merupakan salah satu contoh dari publisitas dari salah satu media (kabar Sulsel) yang mempublis kegiatan sosial Rumah Zakat Cabang Makassar di Kelurahan Lembo, Kecamatan Tallo, Makassar. Dan publisitas ini dilakukan secara gratis atau tidak dipungut biaya oleh media tersebut kepada Rumah Zakat Cabang Makassar.

Kegiatan-kegiatan lembaga/organisasi sosial seperti diatas secara otomatis langsung bisa memberikan dampak positif bagi masyarakat setempat dan dapat mempengaruhi, mengajak, dan memberikan informasi kepada khalayak orang banyak mengenai Rumah Zakat Cabang Makassar melalui media publikasi dimana saja berada.

d. Program Sosialisasi Langsung dengan Masyarakat.

Pelaksanaan strategi LAZNAS Rumah Zakat Cabang Makassar selanjutnya adalah program sosialisasi yang langsung atau berbaur dengan Masyarakat seperti Smile Day dan Pekan Berbagi Senyum.

\section{1.) Smile Day}

Di Makassar, dalam rangka menyambut datangnya bulan suci Ramadhan, RZ (Rumah Zakat) mengajak masyarakat untuk Berbagi Senyum dalam acara Smile Day di Car Free Day (CFD) di Pantai Losari Makassar,

\footnotetext{
${ }^{37}$ Ibid.

${ }^{38}$ www.Kabar-Sulsel.com Aktual dan Terpercaya. Tentang Rumah Zakat Makassar turun ke Lembo (Diakses tanggal 4 september 2014).
} 
Minggu (8/6/2015) kemarin. Hal tersebut dikarenakan senyum merupakan bentuk shadaqah yang paling mudah namun memiliki manfaat yang sangat banyak. Adapun bentuk kampanye yang dilakukan antara lain, Long March Berbagi Senyum, Photo Booth Berbagi Senyum, pemberian makanan dan minuman gratis bagi masyarakat yang sudah berdonasi senyum, serta pemeriksaan kesehatan gratis.

Pada LAZNAS Rumah Zakat Cabang Makassar Acara Smile Day ini pun, juga diproyeksikan sebagai media sosialisasi untuk menyambut datangnya hari raya Idul Adha di tahun ini (2015). Rumah Zakat Cabang Makassar menginisiasinya dengan membagikan camilan kornet Superqurban bagi para pengunjung CFD yang telah mengabadikan foto senyumnya. Ivent ini pun bertujuan untuk membuat masyarakat dengan sukarela membagikan senyumnya, dan merasakan sendiri pengaruh dari senyum tersebut terhadap orang lain.

2.) Pekan Berbagi Senyum

Program yang menyentuh atau menggugah akan membuat masyarakat tertarik mendanainya. Pengembangan selanjutnya dari product dapat terkait misalnya dengan pelibatan para donatur (muzakki) untuk terjun langsung ke lapangan untuk merasakan bagaimana merealisasikan program Rumah Zakat Cabang Makassar. Pada sebagian muzakki ini menjadi sangat menarik sebab pada sebagian orang ada yang sangat puas saat ia bisa menolong orang lain "dengan tangannya sendiri".

Salah satu contoh dampak program sosialisasi yang adalah program pekan berbagi senyum. Pekan Berbagi Senyum adalah kegiatan sosial yang dilaksanakan secara sukarela oleh masyarakat umum untuk berbagi ilmu yang mereka pahami dan kuasai kepada masyarakat di wilayah binaan (ICD) Rumah Zakat Cabang Makassar.

Sebenarnya, kegiatan pekan program berbagi senyum ini tak hanya mengajak masyarakat umum untuk berbagi ilmu semata. Akan tetapi berbagi apa saja yang mereka punyai untuk berbagi kepada sesama termasuk tenaga dan lain-lain.

e. Relawan: Sumber Kekuatan Organisasi Rumah Zakat

Strategi atau cara atau metode-metode yang digunakan oleh Rumah Zakat Cabang Makassar diatas merupakan sarana yang digunakan untuk lebih dekat dengan masyarakat secara luas baik dengan tujuan mensosialisasikan program maupun produk atau dengan menjadikan LPZ ini sebagai lembaga filantropi yang eksistensinya adalah untuk lebih mengedapankan kepedulian sesama.

Di Makassar, Relawan Rumah Zakat ini merupakan ujung tombak dari segalah aksi sosial yang diadakan oleh Rumah Zakat Cabang Makassar mulai dari Smile day, Pekan Berbagi Senyum, Aksi siaga sehat dan aksi-aksi lingkungan lainnya yang sengaja di ciptakan untuk memobilisasi kegiatan disegala lini. Salah satu contohnya adalah Rumah Zakat Cabang Makassar bersama Relawan Rumah Zakat Makassar menggelar aksi Siaga Bencana dengan menyalurkan 220 paket Superqurban 
dan kompor gas serta regulatornya sebanyak 55 unit untuk $55 \mathrm{KK}$, korban kebakaran di Kelurahan Maricaya, RT 02/RW 03, Makassar, Kamis (30/10/2015).

Sebagai contoh lainya RZ (Rumah Zakat) Cabang Makassar melakukan aksi peduli lingkungan dengan menanam 500 ratus pohon mangrove di Kelurahan Untia, Kecamatan Biringkanaya, Makassar. Kegiatan ini dilakukan untuk menindaklanjuti program Ayo "Hijaukan Idonesia" dalam menjaga dan melestarikan lingkungan.

Aksi penanaman pohon diikuti oleh 17 anggota relawan Rumah Zakat Makassar. "Senang bisa berbagi, walaupun penuh dengan lumpur. Tetapi semangat kita tak pernah turun untuk berbagi kepedulian bagi lingkungan. Semoga apa yang kita berikan kepada masyarakat bisa bermanfaat bagi kelangsungan hidup mereka," papar Ramli, Relawan Rumah Zakat Cabang Makasaar. Hamzah menambahkan, kedatangan RZ sangat membantu masyarakat setempat. Ia berharap dengan adanya kegiatan ini, penanaman mangrove di wilayahnya terus bertambah dan berlanjut demi kelestarian yang berkesinambungan. Penanaman pohon ini merupakan salah satu program Rumah Zakat peduli lingkungan yaitu Aksi Menanam Pohon untuk Senyum Indonesia. Aksi penanaman yang memasuki tahap ke-2 ini, rencananya akan dilakukan di 15 kota lainnya hingga akhir Desember 2015. ${ }^{39}$

Tak hanya sampai disitu, Relawan Rumah Zakat berfungsi sebagai wadah pembinaan sekaligus menciptakan SDM yang siap menjadi pelopor terciptanya keseimbangan atas kesenjangan sosial yang terjadi ditengah-tengah masyarakat khususnya kota Makassar.

\section{Bebarapa Kendala Pada LAZNAS Rumah Zakat Cabang Makassar.}

Secara umum kendala atau hambatan yang paling menonjol dalam pengelolaan dana zakat adalah:

a.) Pemahaman umat Islam tentang zakat masih sangat minim dibanding pemahaman mereka tentang shalat, puasa, dan kewajiban syariat lainnya.

b.) Konsep fikih zakat yang dipahami masyarakat dan dipelajari masyarakat tidak lagi sesuai dengan kondisi sosio-kultural dan perekonomian bangsa. Misalnya saja tentang zakat perusahaan dan zakat profesi, sehingga banyak sumber dana yang belum tergali.

c.) Kurangnya kepercayaan masyarakat kepada lembaga pengelola zakat karena dipandang belum amanah. Akhirnya sebagian masyarakat masih menggunakan pola tradisional, yakni memberikan zakat langsung kepada ulama dan tokoh masyarakat disekitarnya.

d.) Belum adanya dukungan politik secara penuh dari pemerintah. Dukungan pemerintah terhadap lembaga pengelola zakat selama ini dinilai masih setengah-setengah. Padahal tanpa dukungan tersebut, zakat tidak akan pernah menjadi gejala objektif masyarakat yang bersifat nasional. Oleh sebab itu

${ }^{39}$ Ramli, Koordinator Relawan Nusantara: Newsroom Kegiatan Relawan Rumah Zakat Cabang Makassar (Wawancara oleh penulis di Kantor Rumah Zakat Cabng Makassar Jl. Sunu no. 32B Makassar, yangdiola pada tanggal 05 November 2015). 
Organisasi Pengelola Zakat harus berusaha sendiri untuk menarik masyarakat agar menyalurkan zakat mereka melalui lembaga resmi. ${ }^{40}$

\section{PENUTUP}

\section{Kesimpulan.}

Setelah melalui beberapa tahap pengolahan serta analisis data penelitian tentang Implementasi Sosialisasi Produk pada Rumah Zakat Cabang Makassar, maka peneliti dapat mengambil kesimpulan sebagai berikut:

1. Pada Rumah Zakat Cabang Makassar hanya terdapat dua jenis pelaksanaan sosialisasi yakni kunjungan formal dan kunjungan non formal.

Adapun kunjungan formal Rumah Zakat Cabang Makassar merupakan bentuk implementasi dalam rangka mensosialisasikan produk hingga kinerja rumah zakat dengan bebrapa lembaga hingga tercipta mitra corporation (Corporation Strategy) atau berusaha menjalin hubungan bilateral kerjasama secara formal antara individu-individu, kelompok-kelompok atau organisasiorganisasi dan instansi-insatansi untuk mencapai suatu tugas atau tujuan tertentu dengan lembaga-lembaga yang dimitrai tersebut.

Sedangkan kunjungan non formal merupakan sarana implementasi sosialisasi rumah zakat kepada masyarakat yang menggunakan sarana media teknologi untuk menginformasikan produk-produk rumah zakat serta sebagai alat guna mengkomunikasikan atau menyampaikan informasi secara langsung akan produk-produknya kepada masyarakat secara luas.

Pun demikian, metode sosialisasi dengan menggunakan kedua kunjungan diatas merupakan hal yang paling efektif dan merupakan implementasi dari teoriteori yang dianggap paling baik untuk melakukan sosialisasi bagi Rumah Zakat Cabang Makassar dikarenakan berhubungan langsung dengan masyarakat dan lembaga yang dimitrai tersebut.

2. Secara mendasar, Rumah Zakat Cabang Makassar memiliki dua Kendala dalam pelaksanaan sosialisasi produknya. Yakni kendala secara internal dan kendala secara eksternal.

Kendala internal adalah kendala-kendala dalam lungkup organisasi atau Lembaga Pengumpul Zakat (LPZ) Rumah Zakat Cabang Makassar yang meliputi faktor keuangan/dana zakat yang sering terlambat dari donator , motivasi atau semangat member (muzakki) yang harus di tingkatkan secara kontinuitas dan kurang memadainya SDM pada tingkat relawan pada saat kegiatan sosialisasi program/produk yang telah ddiagendakan. Hal ini dikarenakan sebagian besar SDM realawan terdiri dari mahasiswa.

Adapun kendala sosialisasi secara eksternal pada Rumah Zakat Cabang Makassar adalah kendala-kendala dalam pelaksanaan sosialisasi diluar lingkup organisasi atau yang berkaitan dan terlibat secara langsung dengan masyarakat. Kendala secara eksternal ini hanya terletak pada kesadaran masyarakat Makassar

\footnotetext{
${ }^{40}$ Tulus, Berderma untuk Semua: Kebijakan Pemerintah dalam Pengelolaan Zakat dan Waqaf (Jakarta: Pusat Bahasa dan Budaya UIN Syarif Hidayatullah, 2003), h. 253.
} 
yang belum sepenuhnya menyadari pentingnya mengeluarkan sebagian hartanya khususnya zakat dalam membangun pondasi ekonomi masyarakat agar lebih mandiri secara financial serta dapat mencukupi kebutuhan masyarakat tidak mampu pada khususnya.

\section{DAFTAR PUSTAKA}

Al-Qur'an Al-Karim

Al-Qardhawi, Yusuf. Al-Ibadah fil-Islam ( Beirut: Muassasah Risalah, 1993).

Ash-Shiddieqy, M Hasbi. Pedoman Zakat (Semarang: PT. Pustaka Rizki Putra; April 2010)

Beik. Irfan Syauqi, Masa Depan Zakat di Indonesia (Ripublika, 2 Septemberi 2009).

Fuad. Anis dan Kandung Sapto Nugroho, Panduan Praktis Penelitian Kualitatif (Yogyakarta: Garaha Ilmu; 2014).

JL. Gibson, Ivancevich JM., dan Donnelly JH., jr., Organizations: Behavior, Structure and Process (Boston, 1994), Terj. Irwin, Organisasi: Perilaku, Struktur dan Proses (Jakarta: Publishing).

Kurniawati, Kedermawanan Kaum Muslimin (Jakarta: Piramedi, 2004).

Moleong. Lexy J., Metodologi Penelitian Kualitatif (Bandung: PT. Rosda Karya; 2005).

Mulyana. Dedy, Metodologi Penelitian Kualitatif: Paradigma Baru Ilmu Komunikasi dan Ilmu Sosial Lainnya (Bandung: PT. Remaja Rosdakarya, 2004)

Norton. M, Menggalang Dana: Penuntun bagi Lembaga Swadaya Masyarakat dan Organisasi Sukarela di negara-negara Selatan (Jakarta: Yayasan obor Indonesia, 2002).

Sadewo. Eri, Manajemen Zakat: Tinggalkan 15 tradisi, Terapkan 4 Prinsip Dasar (Ciputat; Teraju Mizan, 2003).

Supranto, J.. Metode Riset dan Aplikasinya dalam Pemasaran (Jakarta: Fakultas Ekonomi Universitas Indonesia; 1986).

Undang-Undang Republik Indonesia No. 38 Tahun 1999 dan No. 23 Tahun 2011 Tentang Pengelolaan Zakat. 